\title{
Identification of priority areas for conservation in Argentina: quantitative biogeography insights from mygalomorph spiders (Araneae: Mygalomorphae)
}

\author{
Nelson Ferretti • Alda González • \\ Fernando Pérez-Miles
}

Received: 8 April 2014/ Accepted: 29 October 2014/Published online: 2 November 2014

(C) Springer International Publishing Switzerland 2014

\begin{abstract}
Conservation biogeography involves the application of biogeographical principles and methods to conservation issues. The identification of areas of endemism is important for both historical biogeography and conservation. Mygalomorphs spiders have poor vagility, limited dispersal mechanisms and sedentary habits. In this study we use a panbiogeographical approach (through track analysis) and the optimality criterion (NDM) to analyze the distributional patterns in order to identify areas of endemism and to prioritize areas for conservation in Argentina. We identified seven generalized tracks and four biogeographical nodes. The analysis of the $2^{\circ}$ matrix examined by NDM allowed the identification of eight areas of endemism; from the analysis of the $1.5^{\circ}$ matrix, NDM resulted in three areas of endemism; and the analysis of the $1^{\circ}$ and $0.5^{\circ}$ matrices identified one area of endemism each. The more relevant areas identified in this study were located at the Atlantic Forest, Pampa, Monte and Chaco. Other identified areas were Yungas and the hilly systems of Ventania and Tandilia (southern Pampa). We suggest that these results can indicate where to prioritize investment in creating new protected areas, in order to preserve the processes that generate the biogeographic patterns exhibited by this biota.
\end{abstract}

N. Ferretti $(\bowtie) \cdot$ A. González

Centro de Estudios Parasitológicos y de Vectores CEPAVE

(CCT-CONICET-La Plata), UNLP, Calle 2 No 584,

1900 La Plata, Argentina

e-mail: nferretti@conicet.gov.ar

F. Pérez-Miles

Sección Entomología, Facultad de Ciencias, Iguá 4225,

11400 Montevideo, Uruguay
Keywords Conservation biogeography $\cdot$ Endemism · Argentinean spiders · South America

Conservation biogeography is an emerging discipline that involves the application of biogeographical principles and methods to conservation issues including designing of protected areas and planning frameworks (Whittaker et al. 2005; Richardson and Whittaker 2010; Arzamendia and Giraudo 2012). As a result, in recent decades there has been an increased number of contributions that have applied biogeographical principles and methods to evaluate and designate priority areas for biodiversity conservation (Contreras et al. 2001; Álvarez Mondragón and Morrone 2004; Arzamendia and Giraudo 2004, 2012).

The identification of areas of endemism is important for both historical biogeography and conservation (Szumik et al. 2002; Domínguez et al. 2006). Areas of endemism assist in the identification of priorities for biodiversity conservation (Myers et al. 2000). Consequently, their definition, conceptual, as well as methodology, plays an essential role in biogeographical analyses (Linder 2001; Ferrari et al. 2010). The basis for the recognition of areas of endemism is the congruent distribution of endemic taxa (Morrone 1994; Szumik et al. 2002), but they are difficult to recognize because the basic biogeographic patterns can be obscured by many factors such as dispersal, extinction, etc. (Domínguez et al. 2006). Some of the used methods to determine areas of endemism are Parsimony Analysis of Endemicity (Morrone 1994), UPGMA (Linder 2001), panbiogeography (Luna Vega et al. 2000; Arzamendia and Giraudo 2012), and the optimality criterion (through VNDN/NDM software; Szumik et al. 2002; Szumik and Goloboff 2004).

The application of Panbiogeography or track methods has been proposed in order to identify priority areas for 
biodiversity conservation (Morrone 1999; Luna Vega et al. 2000; Arzamendia and Giraudo 2012). Areas where two or more generalized tracks intersect are named nodes, and represent the spatial and temporal interrelationships of different biotic and geological components. These nodes would be particularly important for the purposes of conservation because they contain biotic elements from different origins (thus qualifying as 'hot spots') and allow us to select areas with the most biogeographical diversity to protect. This approach takes into account not only the number of species but also the degree of difference between the biota that overlap in the nodes (Morrone and Crisci 1992; Craw et al. 1999).

Then, Szumik et al. (2002) and Szumik and Goloboff (2004) formalized a method for identifying areas of endemism that takes into account the general concept of areas of endemism, where species are scored according to how well their distribution matches a given area (sets of grid cells) and the areas with higher scores are retained (Szumik and Goloboff 2004; Szumik and Roig-Junent 2005).

Although many of the endemic plants and animals in Argentina have been targeted for conservation (Posadas and Miranda-Esquivel 1999; Arzamendia and Giraudo 2004, 2009; Nori et al. 2011; Arzamendia and Giraudo 2012), little focus has been given to the arthropods (RoigJuñent et al. 2001; Roig-Juñent and Debandi 2004). Redak (2000) suggested that multispecies habitat conservation plans must take into account arthropods, including insects and arachnids, if the goal of conserving biodiversity is to be met. Moreover, Wilson et al. (2012) suggested that Mygalomorphae spiders, mainly tarantulas, can and should be used as sentinel species (indicator species). This means taking care of the requirements of all components of these systems, including the generally "unpopular" animals like spiders. Mygalomorph spiders are long-lived and univoltine, and show high local endemicity. They are among the first spiders to be listed as threatened (Ferretti and Pompozzi 2012), but often their low incidence, cryptic habits and burrowing behavior severely limit a useful knowledge about their biology. They are habitat specialists and females and juveniles are sedentary (Coyle and Icenogle 1994).

Biogeographically, mygalomorphs are informative because of their poor vagility, limited dispersal mechanisms and sedentary habits, making them a promising group for biogeographic and conservation biological studies. To date, there are few formal contributions to the biogeography of mygalomorph spiders (Bertani 2001; Bond et al. 2006; Guadanucci 2011; Ferretti et al. 2012a, b). However, Ferretti et al. (2014) tested previous hypothesis of relationships among areas of endemism already proposed for Argentina (Morrone's division) in a strictly historical context based on distributional records of mygalomorph spiders by using PAE and cluster analysis.

In this contribution we use a panbiogeographical approach (through track analysis) and the optimality criterion (NDM) to identify areas of endemism for mygalomorph spiders in Argentina with the main goal of proposing priority areas for conservation. Considering that biogeographical quantitative studies and conservation approaches on mygalomorph spider communities are still scarce, our data could be of special interest for planning future biodiversity and conservation projects.

\section{Methods}

Study area

The study area in southern South America comprises the Argentinean territory (totaling 2,780,440 $\mathrm{km}^{2}$ ) between the $21^{\circ}-54^{\circ} \mathrm{S}$ and $53^{\circ}-71^{\circ} \mathrm{W}$ approximately. The topography of the area includes mountain ranges at the west and plains at the east. The western limit is defined by the Andean chain. To the north and east of the Andes extend in a northsouth direction the subandean ranges. Also, to the south of these there is the mountainous system of Pampean ranges. Southern Argentina is characterized by the arid Patagonic plains between the Andes and the Atlantic Ocean. Towards northeastern Argentina, the topography is characterized by lower ranges in Misiones province and sedimentary gullies. The great Chacoan-Pampean plains extends in central Argentina being subtropical in north (Chacoan) and temperate to the south (Pampean plains). These Pampean plains are interrupted by the mountainous systems of Ventania and Tandilia (Ringuelet 1956).

Species distributional data

The data set used comprised 772 records of mygalomorphs spiders belonging to 55 species present in Argentina (Ferretti et al. 2014). These records derived from field samplings in central Argentina during the period 2008-2012, from material of museum collections, from the Global Biodiversity Information Facility GBIF and reliable records in the literature. The species Acanthogonatus birabeni (Goloboff 1995), A. pissii (Simon 1889), A. parana (Goloboff 1995), Chaco patagonica (Goloboff 1995), C. sanjuanina (Goloboff 1995), C. tecka (Goloboff 1995), Diplura argentina (Canals 1931), D. parallela (Mello-Leitão 1923) and Neocteniza spinosa Goloboff 1987 are known only from their type locality, and because this type of data does not contribute to the individual tracks or the score of NDM, were excluded from the analyses. 


\section{Pattern analyses}

Individual tracks for each species were constructed by plotting geographic coordinates on maps with the Global Mapper 11.0 and connecting them by minimum-spanning trees using the Trazos 2004 extension (Rojas-Parra 2007) with the Arcview 3.2 software (ESRI 1999). To construct generalized tracks, all the individual track maps were printed and then overlapped. Generalized tracks were determined from the areas of overlap of individual tracks. In addition, in order to avoid the ambiguity and the subjective factor produced when overcrowded geographical points are evaluated, the dataset was then analyzed by using the MartiTracks (Echeverria-Londono and MirandaEsquivel 2011) software with the following parameters: cut value $=3, \quad \operatorname{lmin}=3, \quad \operatorname{lmax}=2.5, \quad \operatorname{lmax}$. line $=4$, and min-SI $=0.8$. All individual and generalized tracks were checked through both methods. By using the geographical information system (GIS) we were able to identify nodes, which are the areas where two or more generalized tracks intersect or are superimposed.

The data matrix was then analyzed using the grid-based method of optimality criterion (Szumik et al. 2002). This method assigns, for each species, a score of endemicity (e) to sets of cells (=areas) according to how well the species distribution matches the area. In many studies of this kind, some different grid sizes were used, e.g. $0.25^{\circ}$ and $0.5^{\circ}$ for the provinces of Jujuy and Córdoba in northern Argentina (Aagesen et al. 2009; Nori et al. 2011); a $1^{\circ}$ grid size for northern Argentina (Szumik et al. 2012) and Southern Argentina including the Patagonic region (Domínguez et al. 2006). However, there is no formal argument to use only one grid size, which means that there is no criterion to select any cell size for the study. Then, we analyzed the data set in four different grid sizes $\left(2^{\circ}, 1.5^{\circ}\right.$, $1^{\circ}$ and $0.5^{\circ}$ ). Then, those areas which survive changes in grid size can be considered more strongly and clearly supported by the data (Aagesen et al. 2009). The optimality criterion was performed in NDM version 3.0 (Goloboff 2011), Consensus areas were obtained using $50 \%$ of similarity in species, against any of the other areas in the consensus.

The biogeographic framework used in this study to locate areas of endemism follows Morrone (2001, 2006; Fig. 1).

\section{Results}

Track analysis

We identified seven generalized tracks for Mygalomorphae in Argentina (Fig. 2a, b; Table 1). The first (T1) is located in Pampa and Central Patagonia. The second generalized track identified (T2) located in the biogeographic province of Pampa. Track T3 was situated in Parana Forest, Araucaria angustifolia Forest, Pampa, Chaco, Monte, Central and Subandean Patagonia. The generalized track T4 extended through the Monte and Chaco. Track T5 comprised the Yungas, Chaco, Monte, Pampa, Central and Subandean Patagonia. The generalized track T6 extended through the biogeographic provinces of Parana and Araucaria angustifolia Forest, Chaco and Pampa. Finally, the last generalized track identified (T7) comprised the Parana Forest, Chaco and Pampa.

In the areas where two or more generalized tracks intersected, four nodes were found (Fig. 2c). The first node (N1) was defined by the intersection of the generalized tracks T3, T6 and T7, in the northeastern Argentina at Parana Forest. Overlap of generalized tracks T3, T6 and T7 produced the second node (N2) in central-eastern Argentina (Pampa). The overlap of three generalized tracks: T3, T4 and T5, produced the third identified node (N3) in central-western Argentina located at Monte. Finally, intersection of two generalized tracks, T3 and T6 resulted in the last identified node (N4) in central-northern Argentina at Chaco.

\section{Optimality criterion (NDM)}

The analysis of the $2^{\circ}$ matrix examined 1,816 groups of cells and led to the identification of nine areas of endemism, summarized in eight consensus areas (Fig. 3) with 30 endemic species (Table 2). The consensus areas represent the following areas of endemism: $\mathrm{AC}_{0}$ (Fig. 3a) and $\mathrm{AC}_{4}$ (Fig. 3c) located in Central Eastern and Northeastern Argentina; $\mathrm{AC}_{1}$ (Fig. 3b) and $\mathrm{AC}_{7}$ (Fig. 3d) in Central and Northern Argentina; $\mathrm{AC}_{2}$ in Northwestern, Central and Southwestern Argentina (Fig. 3c); $\mathrm{AC}_{3}$ in Northeastern Argentina (Fig. 3c); $\mathrm{AC}_{5}$ in Central Eastern Argentina (Fig. 3a) and $\mathrm{AC}_{6}$ in Northern Argentina (Fig. 3a). From the analysis of the $1.5^{\circ}$ matrix, NDM examined 1,559 groups of cells resulting in four areas of endemism, summarized in three consensus areas (Fig. 4a) with 10 endemic species (Table 2). The consensus areas represent the following areas of endemism: $\mathrm{AC}_{0}$ in Northeastern Argentina; $\mathrm{AC}_{1}$ in Northern Argentina and $\mathrm{AC}_{2}$ in Central Eastern Argentina. The analysis of the $1^{\circ}$ matrix examined 1,661 groups of cells resulting in two areas of endemism, summarized in one consensus area $\left(\mathrm{AC}_{0}\right.$; Fig. $\left.4 \mathrm{~b}\right)$ with five endemic species (Table 2) located in Northeastern Argentina. Finally, from the analysis of the $0.5^{\circ}$ matrix, NDM examined 1,617 groups of cells resulting in one areas of endemism $\left(\mathrm{AC}_{0} ;\right.$ Fig. 4c) with four endemic species (Table 2) located in Northeastern Argentina. 


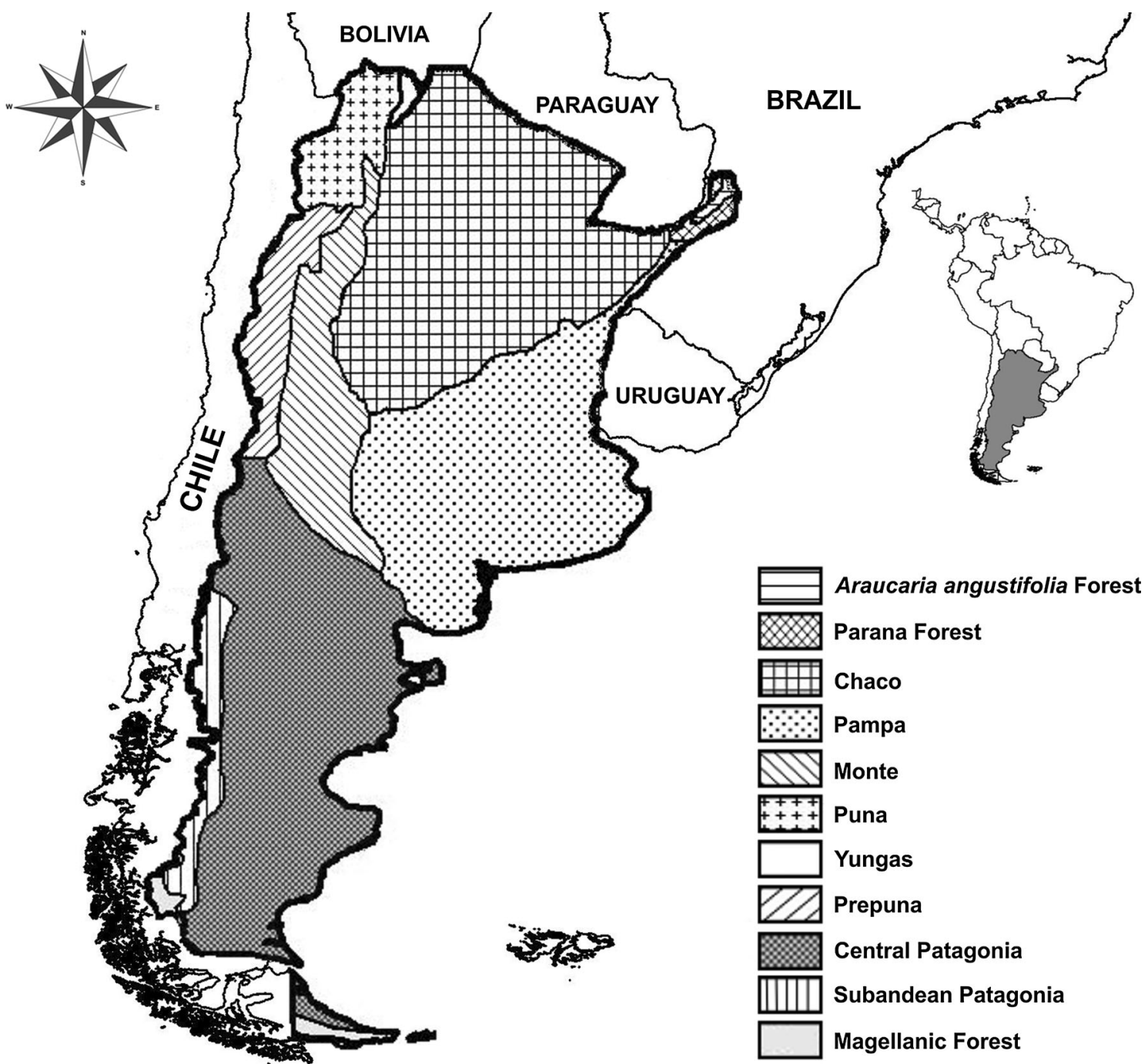

Fig. 1 Map showing the study area involved in the present work with the biogeographic provinces proposed by Morrone (2001, 2006)

\section{Discussion}

High priority areas identified

Node 1 is the richest and priority node formed by the intersection of three generalized tracks. In addition, this area was recovered by NDM with all grid sizes. Arguably, resistance to grid size changes becomes an important factor when evaluating a specific distribution pattern. This biogeographical node is located in the Atlantic Forest (Araucaria angustifolia Forest and Parana forest) at the limit with Chaco biogeographical province (Morrone 2001, 2006). This area could be defined as a region with high species richness and taxonomic elements of different origins that represent the spatial and temporal interrelationships of different biotic and geological components (Spector 2002; Arzamendia and Giraudo 2012; Ferretti et al. 2014). This allows us to protect areas taking into account the number of species but also the degree of difference between the biotas that overlap and their evolutionary processes (Álvarez Mondragón and Morrone 2004). Several authors have pointed out the role of biogeographical intersections in producing high beta diversity, and consequently, these intersections have high species richness (Fjeldså and Rahbek 1997; Spector 2002). Moreover, this area exhibits significant singularity on its fauna and flora composition with many endemic species or species with distributions restricted only to this region in Argentina, including plants, invertebrates and birds (Ponce et al. 2002; Giraudo 2004; López Ruf et al. 2006; Arzamendia and Giraudo 2012). Recently, this area has been identified as an area of endemism under different scales using distributional patterns of plants, mammals, reptiles, birds and insects (Szumik et al. 2007; Ferrari et al. 2010; Szumik et al. 2012).

Node 2 is the second in richness and priority. The optimality criterion through the $2^{\circ}$ grid size identified two 

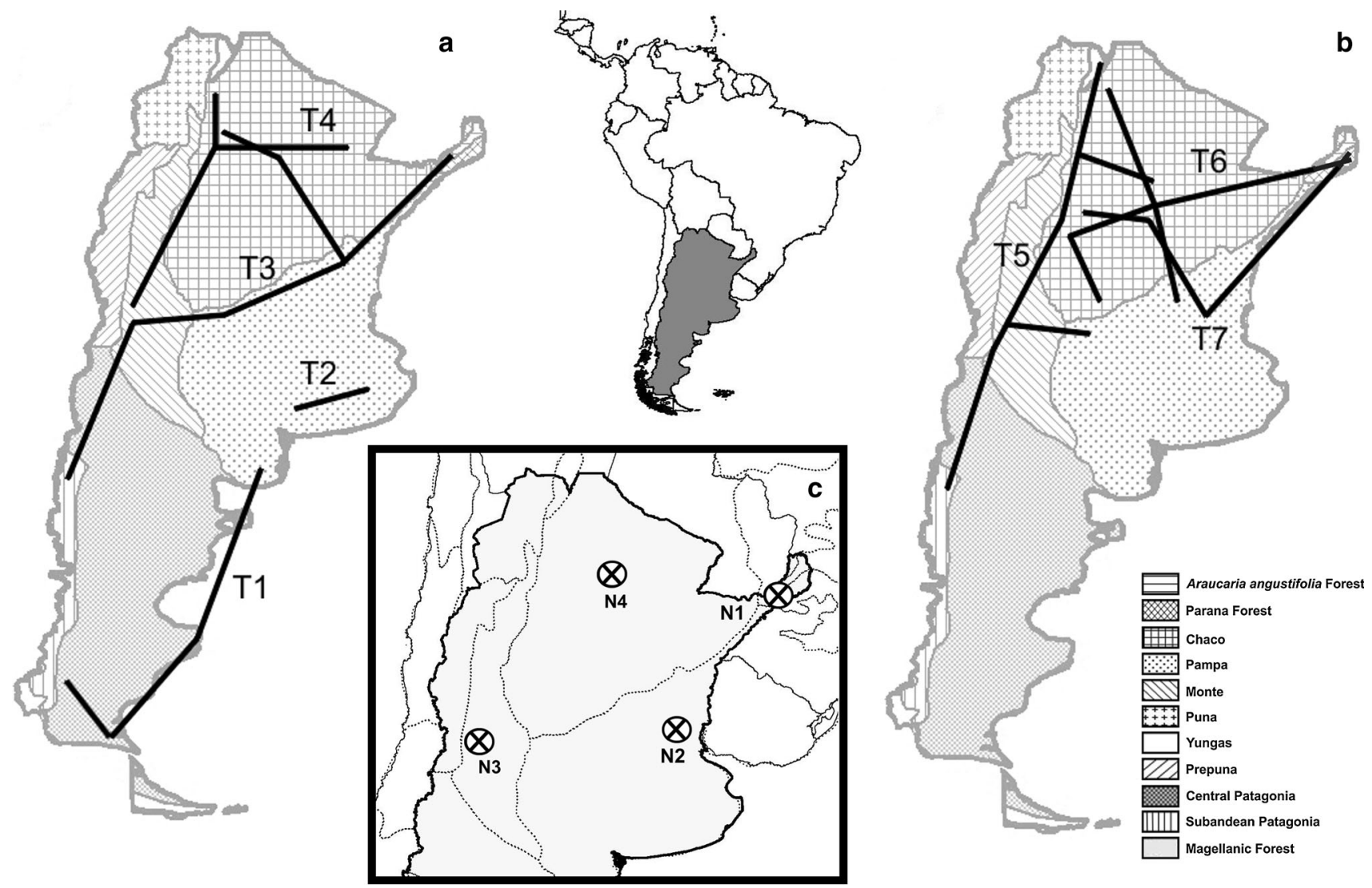

Fig. 2 Generalized tracks and nodes obtained for Mygalomorphae spiders in Argentina overlain in the biogeoraphic provinces of Morrone (2001, 2006) a generalized tracks T1-T4 b generalized tracks T5-T7 c biogeographic nodes N1-N4

Table 1 Generalized tracks and supporting species (individual tracks) obtained with track analysis

Generalized Species (individual tracks)

tracks

\begin{tabular}{|c|c|}
\hline $\mathrm{T} 1$ & A. fuegianus and A. patagonicus. \\
\hline $\mathrm{T} 2$ & G. doeringi, G. vachoni, C. simoni and M. thorelli \\
\hline $\mathrm{T} 3$ & $\begin{array}{l}\text { A. centralis, } C . \text { argentinense, } C . \text { misionensis, } \\
\text { G. burzaquensis, H. uruguayensis, } N . \text { australis, } \\
\text { N. chancani, } P . \text { longisternale, S. iguazu, S. palmar, } \\
\text { S. quena and } S . \text { tenuistyla. }\end{array}$ \\
\hline $\mathrm{T} 4$ & $\begin{array}{l}\text { A. sternalis, } C \text {. obscura, I. hirsutipedis, I. annulata } \\
\text { and } M . \text { crassifemur. }\end{array}$ \\
\hline T5 & $\begin{array}{l}\text { A. notatus, E. truculentus, D. bonariensis, D. ornata, } \\
\text { G. inermis, L. longipes, N. minima, N. toba and } \\
\text { P. scrofa. }\end{array}$ \\
\hline Te & $\begin{array}{l}\text { A. chacoana, A. cordubensis, C. tucumana, } \\
\text { G. grossa, G. anthracina, P. modesta, S. uruguai } \\
\text { and V. paranaensis. }\end{array}$ \\
\hline & $\begin{array}{l}\text { A. suina, D. paraguayensis, E. campestratus, } \\
\text { E. weijenberghi, I clarus y } S . \text { platensis. }\end{array}$ \\
\hline
\end{tabular}

nested areas of endemism: the first $\left(\mathrm{AC}_{0}\right)$ located in the biogeographical provinces of Pampa, Chaco and southern Parana Forest (Morrone 2001, 2006); and the second $\left(\mathrm{AC}_{4}\right)$ as a sub-area of the first restricted to the province of Pampa matching with the location of the biogeographic node. In Pampa, one area of endemism was identified based on insects (Coleoptera) and has been reported at the east and northern of Buenos Aires province (Casagranda et al. 2009). Also, another area of endemism in Pampa, mainly in Córdoba (central Argentina), was identified by Nori et al. (2011) for reptiles, but not strongly supported by the data. The area of endemism obtained in this study at the margins of the Uruguay River contains the southernmost remnants of Atlantic forest, forming gallery forest along the river bank and islands of the Uruguay River, and representing the southernmost limit of distribution for several tropical species (mainly Atlantic-Parana species) of plants, birds and reptiles (Nores et al. 2005; Arzamendia and Giraudo 2009, 2012). This shows the importance of the floodplain's gallery forest and wetlands as key habitats [i.e. most of the Stenoterommata species can be found in this type of habitats (Goloboff 1995)] in conservation strategies. According to some authors, many species require wetlands as well as adjacent high lands, and this means that applying the classic conservation strategies separately to freshwater or highlands are not enough: a landscape-level approach is 


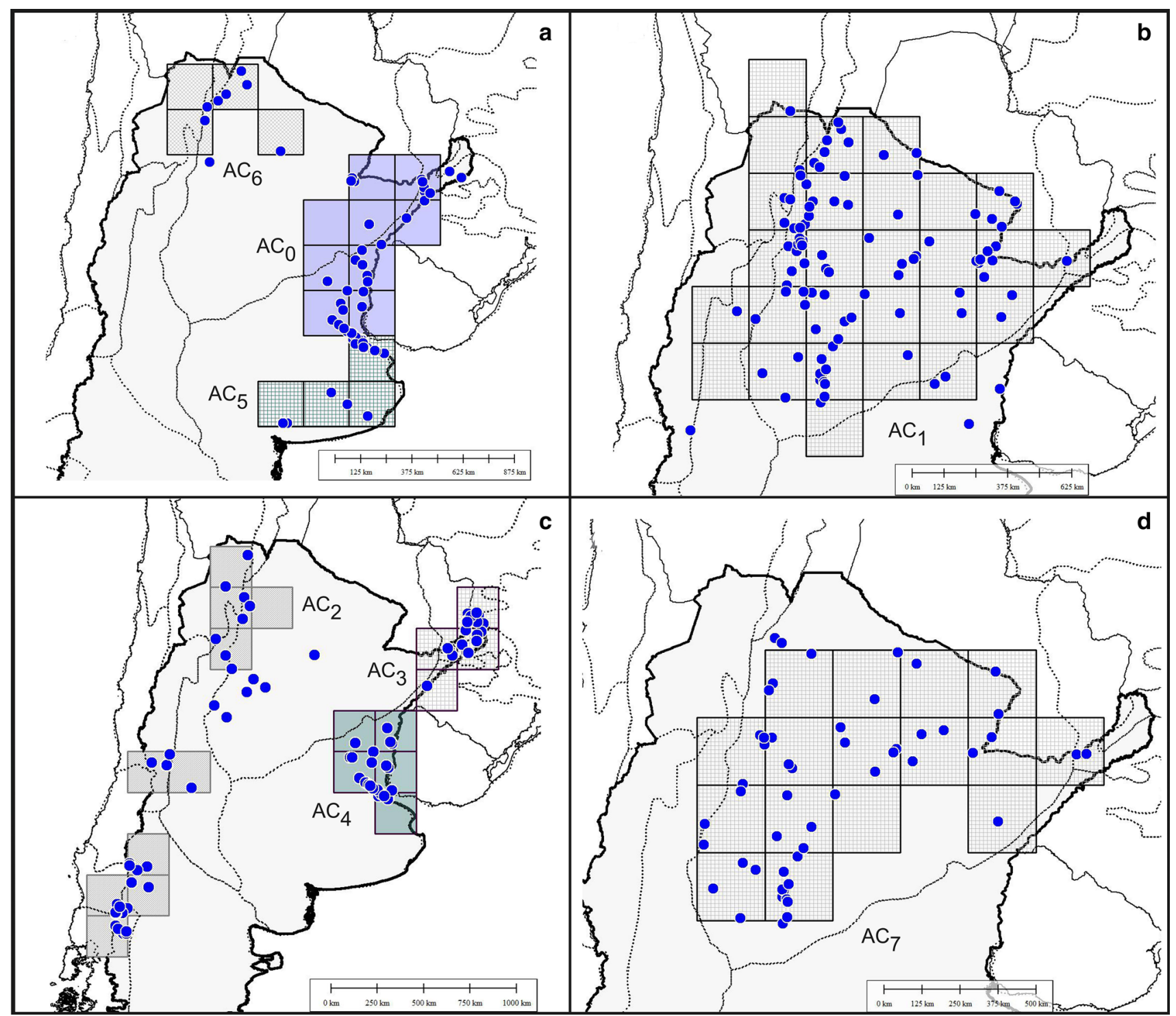

Fig. 3 Endemic areas obtained from the optimality criterion (NDM) of the Mygalomorphae recognized in $2^{\circ}$ grid in $\mathrm{Argentina}$ a set $\mathrm{AC}_{0}, \mathrm{AC}_{5}$ and $\mathrm{AC}_{6} \mathrm{~b}$ set $\mathrm{AC}_{1} \mathbf{c}$ set $\mathrm{AC}_{2}, \mathrm{AC}_{3}$ and $\mathrm{AC}_{4} \mathbf{d}$ set $\mathrm{AC}_{7}$

necessary to protect the biodiversity in the large river floodplains and the surrounding land (Arzamendia and Giraudo 2012).

The third conservation priority is Node 3, in the Monte at central western Argentina (Mendoza province). Through NDM, we identified one disjunctive area of endemism in central-western Argentina; where two cells were located at Prepuna and Monte (Morrone 2001, 2006). This area of endemism has been proposed for insect taxa along with Central Monte, located in La Rioja province reaching southern Mendoza province. These areas resulted of the mixing of neotropic and patagonic biotic components (Roig-Juñent et al. 2001). This area, identified as a nested area for insects, known as Occidental Patagonia (Domínguez et al. 2006), has been considered as a unique biogeographic unit unrelated with Central Patagonia and Subandean Patagonia (Ferretti et al. 2014). The relevance for the conservation of this area has been put forward by Roig-Juñent et al. (2001) and Domínguez et al. (2006), given by the numerous endemic species and the richness of relictual species (Löwenberg-Neto and de Carvalho 2009). Arguably, most of the natural reserves that actually are located in the biogeographical province of Monte include the area of endemism of Central Monte, thus containing the biogeographical node identified in this study in Mendoza province. Nevertheless, the need for the proposal and creation of more preservative areas in Monte region is highlighted with the goal to protect numerous endemic species allowing the preservation of biodiversity as much as possible. 
Table 2 Areas of endemism of the Mygalomorphae in Argentina obtained with NDM, species supporting each area, endemicity value (e), grid size, and biogeographical provinces (Morrone 2001, 2006)

\begin{tabular}{|c|c|c|c|c|}
\hline & Species & $\begin{array}{l}\text { Endemicity } \\
\text { value (e) }\end{array}$ & $\begin{array}{l}\text { Grid } \\
\text { size }\end{array}$ & Biogeographical provinces \\
\hline \multicolumn{5}{|c|}{ Endemic area $2^{\circ}$ grid squares } \\
\hline $\mathrm{AC}_{0}$ & $\begin{array}{l}\text { Acanthoscurria suina, Grammostola anthracina, Hommoeoma } \\
\text { uruguayense and Stenoterommata palmar }\end{array}$ & $2,106-2,356$ & 8 & Parana Forest, Chaco and Pampa \\
\hline $\mathrm{AC}_{1}$ & $\begin{array}{l}\text { Acanthoscurria sternalis, Grammostola pulchripes, Ischnothele } \\
\text { annulata and Pycnothele modesta }\end{array}$ & $2,811-3,061$ & 27 & $\begin{array}{l}\text { Parana Forest, Chaco, Pampa, Yungas, } \\
\text { Puna, Prepuna and Monte }\end{array}$ \\
\hline $\mathrm{AC}_{2}$ & Euathlus truculentus, Lycinus longipes and Paraphysa scrofa & $2,134-2,384$ & 10 & $\begin{array}{l}\text { Chaco, Monte, Yungas, Puna, Prepuna, } \\
\text { Central Patagonia and Subandean } \\
\text { Patagonia }\end{array}$ \\
\hline $\mathrm{AC}_{3}$ & $\begin{array}{l}\text { Diplura paraguayensis, Eupalaestrus campestratus, Homoeomma } \\
\text { elegans, Rachias timbo, Stenoterommata iguazu and } \\
\text { Stenoterommata uruguai }\end{array}$ & $3,950-4,200$ & 4 & $\begin{array}{l}\text { Araucaria angustifolia Forest, Parana } \\
\text { Forest, Chaco and Pampa }\end{array}$ \\
\hline $\mathrm{AC}_{4}$ & $\begin{array}{l}\text { Homoeomma uruguayense, Stenoterommata tenuistyla and } \\
\text { Xenonemesia platensis }\end{array}$ & $2,300-2,550$ & 5 & Chaco and Pampa \\
\hline $\mathrm{AC}_{5}$ & $\begin{array}{l}\text { Calathotarsus simoni, Grammostola burzaquensis and } \\
\text { Mecicobothrium thorelli }\end{array}$ & $2,500-2,750$ & 4 & Pampa \\
\hline $\mathrm{AC}_{6}$ & $\begin{array}{l}\text { Chaco obscura, Cyriocosmus versicolor, Neocteniza minima and } \\
\text { Neocteniza toba }\end{array}$ & $2,931-3,181$ & 4 & Chaco, Monte, Yungas and Puna \\
\hline $\mathrm{AC}_{7}$ & $\begin{array}{l}\text { Acanthoscurria chacoana, Idiops hirsutipedis, Ischnothele annulata } \\
\text { and Pycnothele modesta }\end{array}$ & $2,646-2,896$ & 16 & Parana Forest, Chaco and Monte \\
\hline \multicolumn{5}{|c|}{ Endemic area $1.5^{\circ}$ grid squares } \\
\hline $\mathrm{AC}_{0}$ & $\begin{array}{l}\text { Eupalaestrus campestratus, Homoeomma elegans, Rachias timbo, } \\
\text { Stenoterommata iguazu and Stenoterommata uruguai }\end{array}$ & $3,875-4,125$ & 3 & $\begin{array}{l}\text { Araucaria angustifolia Forest and Parana } \\
\text { Forest }\end{array}$ \\
\hline $\mathrm{AC}_{1}$ & Chaco obscura, Cyriocosmus versicolor and Neocteniza minima & $2,100-2,350$ & 4 & Chaco and Yungas \\
\hline $\mathrm{AC}_{2}$ & Calathotarsus simoni and Mecicobothrium thorelli & $2,000-2,250$ & 2 & Pampa \\
\hline \multicolumn{5}{|c|}{ Endemic area $1^{\circ}$ grid squares } \\
\hline $\mathrm{AC}_{0}$ & $\begin{array}{l}\text { Eupalaestrus campestratus, Homoeomma elegans, Rachias timbo, } \\
\text { Stenoterommata iguazu and Stenoterommata uruguai }\end{array}$ & $2,928-3,428$ & 7 & $\begin{array}{l}\text { Araucaria angustifolia Forest and Parana } \\
\text { Forest }\end{array}$ \\
\hline \multicolumn{5}{|c|}{ Endemic area $0.5^{\circ}$ grid squares } \\
\hline $\mathrm{AC}_{0}$ & $\begin{array}{l}\text { Homoeomma elegans, Rachias timbo, Stenoterommata iguazu and } \\
\text { Stenoterommata uruguai }\end{array}$ & $2,476-2,726$ & 7 & $\begin{array}{l}\text { Araucaria angustifolia Forest and Parana } \\
\text { Forest }\end{array}$ \\
\hline
\end{tabular}

Finally, the node N4 is the last in priority and was located in Chaco at central northern Argentina. The combined areas of Chaco and Yungas or Chaco obtained through NDM as an area of endemism have been identified for numerous taxa, such as plants, reptiles, amphibians, birds, mammals, insects and opilionids (Morrone 2001; Acosta 2002; Nori et al. 2011; Szumik et al. 2012). The identification of combination of patches from Yungas with the western portion of the biogeographical province of Chaco could be in relation to some tree species of Premontane Forest that occasionally appear within Chaco (Prado 1995). They are also usually related to gallery forests and they are considered of 'non-chacoan lineage' or as 'subtropical forest transchacoan elements'. Moreover, during the climatic fluctuations of the Pleistocene, according to Prado (1995), the Yungas covered the whole of northern Argentina (reaching Córdoba province to the South) and these patches are remnants of that formation.

The adequate protection of Nodes 1, 2, 3 and 4 would preserve approximately $89 \%$ of the species studied, because of the high complementarity of the nodes and their efficiency with respect to representing endemic species and areas of high richness.

\section{Other relevant areas recovered with NDM}

Yungas was recovered from NDM as an area of endemism. The limits of the area reach the biogeographic province of Chaco to the east and Prepuna to the west (Morrone 2001, 2006). Using $2^{\circ}$ grid sizes many cells occurred outside from the area of endemism, i.e. in the biogeographic provinces of Chaco, Puna and Prepuna. Furthermore, in the $1.5^{\circ}$ grid size, two cells fell outside the area in the biogeographic province of Chaco. The inclusion of those cells is not strongly supported by the data (i.e. removing them diminish the endemicity score no more than 1-3\% of the score of the respective areas), but is supported nonetheless (i.e. the endemicity score does decrease when removing them). When much more detailed data is available, this 


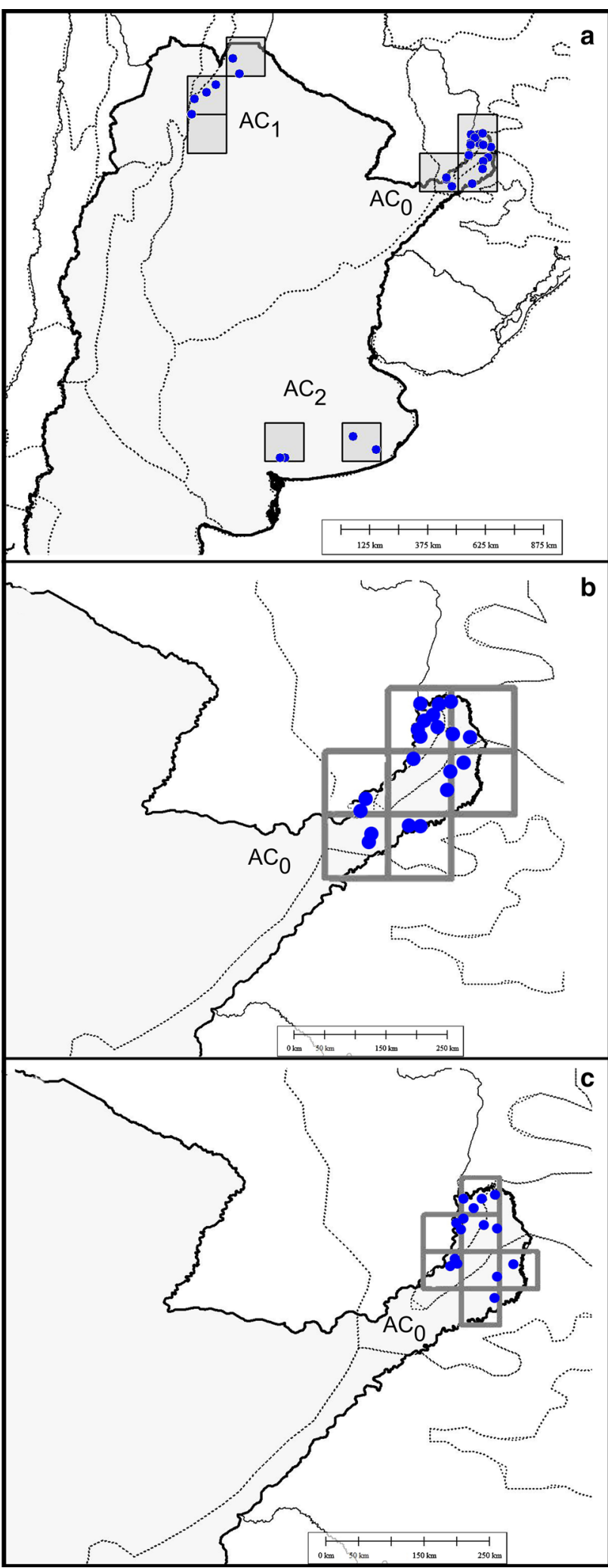

Fig. 4 Endemic areas obtained from the optimality criterion (NDM) of the Mygalomorphae recognized in a $1.5^{\circ}$ grid $\mathbf{b} 1^{\circ}$ grid and $\mathbf{c} 0.5^{\circ}$ grid would probably be remedied by using smaller grid sizes, but (given the low density of the records known at the present), the smaller grid sizes produce very low scores of endemicity and a more diffuse identification of areas of endemism. Consequently, some of the species identified in this area as "endemic", in fact occur in other environments, i.e. Cyriocosmus versicolor and Neocteniza toba. Arguably, this could be related to the existence of a Premontane Forest in western Chaco that is transitional with the Yungas (Ayarde 1995; Morrone 2001; Aagesen et al. 2009). The Yungas has been identified as area of endemism by numerous authors for different taxa, highlighting the relevance of this area to establish conservation priorities (Ponce et al. 2002; López Ruf et al. 2006; Szumik et al. 2007; Löwenberg-Neto and de Carvalho 2009; Ferrari et al. 2010; Szumik et al. 2012). Also, this area is home of numerous animals and plant species that represents a richness of $40 \%$ of the entire country, in less of $2 \%$ of the Argentinean territory. In Argentina, $11 \%$ of the Yungas area is actually under protection, mostly on the northern portion of this area (Di Bitteti et al. 2011). However, in central and western Yungas, particularly in Salta province, protected areas are scarce.

The hilly systems of Ventania and Tandilia in southern Buenos Aires province were recovered with NDM using the grid sizes of $2^{\circ}$ and $1.5^{\circ}$. Calathotarsus simoni (Migidae) is a trapdoor spider endemic from the mountain systems of Ventania and Tandilia (Schiapelli and Gerschman de Pikelin 1975) and M. thorelli (Mecicobothriidae) is reported for Ventania and Tandilia in Argentina and in southern Uruguay is present in Sierra de las Ánimas (Ferretti et al. 2012a). The Mygalomorph species of this area of endemism comprise an important group of sedentary and cryptozoic spiders that seem to be highly dependent on habitat type and environmental factors (Ferretti et al. 2012c). The diversity and abundance of these spiders in this area is higher in relation to other areas (Ferretti et al. 2012c), and the microclimatic conditions and vegetation of these hilly systems could provide a suitable habitat for these cryptozoic species (Lizzi et al. 2007). Roig-Juñent and Debandi (2004) identified an area of endemism and also proposed the mountainous systems of Ventania and Tandilia to be considered as with high conservation priorities areas. This area shows numerous relictual genera and even an endemic tribe of insects (Carabidae, Notiokasini). Moreover, their biota shows peculiar affinities with that of southern Africa and other pangeic regions of South America (Mattoni and Acosta 1997).

This study highlights the relevance of certain areas of particular interest to biodiversity conservation in Argentina, which resulted from the identification of biogeographical 
nodes through a panbiogeographical approach and areas of endemism with NDM. The nodes allow for the inclusion of evolutionary and ecological traits during conservation assessment and planning, and this helps improve reserve networks and therefore increases the effectiveness of the resources invested in conservation of the biodiversity (Arzamendia and Giraudo 2012).

Finally, although a reasonable number of distributional data of mygalomorph spiders allowed the identification of many areas of endemism in Argentina, it is still necessary to explore this field of study and obtain more information from Museums' material and field works. This new information could allow the delimitation of such areas with a more detailed resolution, establishing their relevance in agree to their "gamma" diversity, endemism degree and the occurrence of relictual taxa inside them. For the forgoing reasons, we suggest that these results can be taken as an indicative guide as to where it might be more efficient to invest in creating new protected areas, in order to preserve the processes that generate the biogeographic patterns exhibited by this biota.

Acknowledgments Nelson Ferretti and Alda González are grateful to CONICET (Consejo Nacional de Investigaciones Científicas y Técnicas). We would like to thank C. Scioscia, M. Ramírez and C. Grismado for their help during the scientific stage at the Museo Argentino de Ciencias Naturales "Bernardino Rivadavia", Argentina.

\section{References}

Aagesen L, Szumik CA, Zuloaga FO, Morrone O (2009) Quantitative biogeography in the South America highlands-recognizing the Altoandina, Puna and Prepuna through the study of Poaceae. Cladistics 25:295-310

Acosta LE (2002) Patrones zoogeográficos de los opiliones argentinos (Arachnida: Opiliones). Revista Ibérica de Aracnología 6:69-84

Álvarez Mondragón E, Morrone JJ (2004) Propuesta de áreas para la conservación de aves de México, empleando herramientas panbiogeográficas e índices de complementariedad. Interciencia 29:112-120

Arzamendia V, Giraudo AR (2004) Usando patrones de biodiversidad para la evaluación y diseño de áreas protegidas: las serpientes de la provincia de Santa Fé (Argentina) como ejemplo. Rev Chil Hist Nat 77:335-348

Arzamendia V, Giraudo AR (2009) Influence of large South American rivers of the Plata Basin on distributional patterns of tropical snakes: a panbiogeographical analysis. J Biogeogr 36:1739-1749

Arzamendia V, Giraudo AR (2012) A panbiogeographical model to prioritize areas for conservation along large rivers. Divers Distrib 18:168-179

Ayarde HR (1995) Estructura de un sector de selva pedemontana: reserva fiscal Parque La Florida, Tucumán (Argentina). In: Brown $\mathrm{AD}$, Grau HR (eds) Investigación, conservación y desarrollo en selvas subtropicales de montana. LIEY, San Miguel de Tucumán, pp 69-78

Bertani R (2001) Revision, cladistic analysis, and zoogeography of Vitalius, Nhandu, and Proshapalopus; with notes on other theraphosinae genera (Araneae, Theraphosidae). Arquivos de Zoologia do Estado de São Paulo 36:265-356

Bond JE, Beamer DA, Lamb T, Hedin M (2006) Combining genetic and geospatial analyses to infer population extinction in mygalomorph spiders endemic to the Los Angeles region. Anim Conserv 9:145-157

Canals J (1931) Una nueva Dipluridae. Physis 10:357-361

Casagranda MD, Roig-Junent S, Szumik C (2009) Endemismo a diferentes escalas espaciales: un ejemplo con Carabidae (Coleoptera: Insecta) de América del Sur austral. Rev Chil Hist Nat 82:17-42

Contreras RM, Luna Vega I, Morrone JJ (2001) Conceptos biogeograficos. Elementos 41:33-37

Coyle FA, Icenogle WR (1994) Natural history of the California trapdoor spider genus Aliatypus (Araneae, Antrodiaetidae). $\mathrm{J}$ Arachnol 22:225-255

Craw RC, Grehan JR, Heads MJ (1999) Panbiogeography: tracking the history of life. Oxford University Press, New York

Di Bitteti MS, Albanesi S, Fouget MJ, Cuyckens GAE, Brown AD (2011) The Yungas Biosphere Reserve of Argentina: a hot spot of South American wild cats. Cat News 54:25-29

Domínguez MC, Roig-Junent S, Tassin JJ, Ocampo FC, Flores GE (2006) Areas of endemism of the Patagonian steppe: an approach based on insect distributional patterns using endemicity analysis. J Biogeogr 33:1527-1537

Echeverria-Londono S, Miranda-Esquivel DR (2011) MartiTracks: a geometrical approach for identifying geographical patterns of distribution. PLoS ONE. doi:10.1371/journal.pone.0018460

ESRI (1999) ArcView GIS 3.2. Environmental Systems Research Institute, Inc., New York

Ferrari A, Paladini A, Schwertner CF, Grazia J (2010) Endemism analysis of neotropical pentatomidae (Hemiptera, Heteroptera). Iheringia 100(4):449-462

Ferretti N, Pompozzi G (2012) Grammostola vachoni. The IUCN Red List of Threatened Species. Version 2014.2. http://www.iucnred list.org. Accessed 20 October 2014

Ferretti N, González A, Pérez-Miles F (2012a) Historical biogeography of mygalomorph spiders from the peripampasic orogenic arc based on track analysis and PAE as a panbiogeographical tool. Syst Biodivers 10:179-193

Ferretti N, González A, Pérez-Miles F (2012b) Historical biogeography of the genus Cyriocosmus (Araneae: Theraphosidae) in the neotropics According to an event-based method and spatial analysis of vicariance. Zool Stud 54:526-535

Ferretti N, Pompozzi G, Copperi S, Pérez-Miles F, González A (2012c) Mygalomorph spider community of a natural reserve in a hilly system in central Argentina. J Insect Sci 12:1-16

Ferretti N, González A, Pérez-Miles F (2014) Historical relationships among Argentinean biogeographic provinces based on mygalomorph spider distribution data (Araneae: Mygalomorphae). Stud Neotrop Fauna Environ 49(1):1-10

Fjeldså J, Rahbek C (1997) Species richness and endemism in South American birds: implications for the design of networks of nature reserves. In: Laurance WF, Bierregaard RO Jr (eds) Tropical forest remnants. University of Chicago Press, Chicago, pp 466-482

Giraudo AR (2004) Biodiversidad del Alto Paraná Encajonado. El Alto Paraná Encajonado argentino-paraguayo. In: Matteucci SD, Morello J, Rodríguez A, Mendoza N (eds) Mosaicos de paisaje y conservación regional. Ediciones Fadu and UNESCO, Buenos Aires, pp 141-149

Goloboff PA (1995) A revision of the South American spiders of the family Nemesiidae (Araneae, Mygalomorphae). Part I: species from Peru, Chile, Argentina and Uruguay. B Am Mus Nat Hist 224:1-189

Goloboff P (2011) NDM/VNDM: programs for the identification of areas of endemism, version 3. http://www.zmuc.dk/public/ phylogeny. Accessed 12 June 2012 
Guadanucci JPL (2011) Cladistic analysis and biogeography of the genus Oligoxystre Vellard 1924 (Araneae: Mygalomorphae: Theraphosidae). J Arachnol 39:320-326

Linder HP (2001) On areas of endemism, with an example from the African Restionaceae. Syst Biol 50:892-911

Lizzi JM, Garbulsky MF, Golluscio RA, Deregibus AV (2007) Mapeo indirecto de la vegetacion de Sierra de la Ventana, provincia de Buenos Aires. Ecología Austral 17:217-230

Lopez Ruf M, Morrone JJ, Hernandez EP (2006) Patrones de distribución de las Naucoridae argentinas. Revista de la Sociedad Entomológica Argentina 65(1-2):111-121

Löwenberg-Neto P, de Carvalho CJB (2009) Areas of endemism and spatial diversification of the Muscidae (Insecta: Diptera) in the Andean and Neotropical regions. J Biogeogr 36:1750-1759

Luna Vega I, Alcantara Ayala O, Morrone JJ, Espinosa Organista D (2000) Track analysis and conservation priorities in the cloud forests of Hidalgo, Mexico. Divers Distrib 6:137-143

Mattoni CI, Acosta LE (1997) Scorpions of the insular Sierras in the Llanos District (province of La Rioja, Argentina) and their zoogeographical links. Biogeographica 73(2):67-80

Mello-Leitão CFde (1923) Theraphosideas do Brasil. Rev Mus Pau $13: 1-438$

Morrone JJ (1994) On the identification of areas of endemism. Syst Biol 43:438-441

Morrone JJ (1999) Presentación preliminar de un nuevo esquema biogeográfico de América del Sur. Biogeographica 75(1):1-16

Morrone JJ (2001) Biogeografía de América Latina y el Caribe. M\&T Manuales \& Tesis SEA, Zaragoza

Morrone JJ (2006) Biogeographic areas and transition zones of Latin America and the Caribbean islands based on panbiogeographic and cladistic analyses of the entomofauna. Annu Rev Entomol $51: 467-494$

Morrone JJ, Crisci JV (1992) Aplicación de métodos filogenéticos y panbiogeograficos en la conservación de la diversidad biológica. Evolución Biológica 6:53-66

Myers N, Mittermeier RA, Mittermeier CG, da Fonseca GAB, Kent J (2000) Biodiversity hotspots for conservation priorities. Nature 403:853-858

Nores M, Cerana MM, Serra DA (2005) Dispersal of forest birds and trees along the Uruguay River in southern South America. Divers Distrib 11:205-217

Nori J, Diaz Gomez JM, Leynaud GC (2011) Biogeographic regions of Central Argentina based on snake distribution: evaluating two different methodological approaches. J Nat Hist 45:1005-1020

Ponce M, Mehltreter K, de la Sota ER (2002) Análisis biogeográfico de la diversidad pteridófitica en Argentina y Chile continental. Rev Chil Hist Nat 75:703-717

Posadas P, Miranda-Esquivel DR (1999) El PAE (Parsimony analysis of endemicity) como una herramienta en la evaluacion de la biodiversidad. Rev Chil Hist Nat 72:539-546

Prado DE (1995) Selva Pedemontana: contexto regional y lista florística de un ecosistema en peligro. In: Brown AD, Grau $\mathrm{H}$ (eds) Investigación, conservación y desarrollo en selvas subtropicales de montanas. Laboratorio de Investigaciones Ecológicas de las Yungas (UNT), Tucumán, pp 19-52
Redak RA (2000) Arthropods and multispecies habitat conservation plans: are we missing something? Environ Manag 26:97-107

Richardson DM, Whittaker RJ (2010) Conservation biogeographyfoundations, concepts and challenges. Divers Distrib 16:313-320

Ringuelet RA (1956) Los factores históricos o geológicos en la zoogeografía Argentina. Holmbergia 5(11):1-18

Roig-Juñent S, Debandi G (2004) Prioridades de conservación aplicando información filogenética y endemicidad: un ejemplo basado en Carabidae (Coleoptera) de America del Sur austral. Rev Chil Hist Nat 77:695-709

Roig-Juñent S, Flores G, Claver S, Debandi G, Marvaldi A (2001) Monte Desert (Argentina): insect biodiversity and natural areas. J Arid Environ 47:77-94

Rojas-Parra CA (2007) Una herramienta automatizada para realizar análisis panbiogeograficos. Biogeografía 1:31-33

Schiapelli RD, Gerschman de Pikelin BS (1975) Calathotarsus simoni sp. nov. (Araneae, Migidae). Physis 34:17-21

Simon E (1889) Etudes arachnologiques. 21e Mémoire. XXX. Descriptions de quelques arachnides du Chili et remarques synonymiques sur quelques unes des espèces décrites par Nicolet. Ann Soc Entomol Fr (6) 8:217-222

Spector S (2002) Biogeographic crossroads as priority areas for biodiversity conservation. Conserv Biol 16:1480-1487

Szumik CA, Goloboff P (2004) Areas of endemism: an improved optimality criterion. Syst Biol 53:968-977

Szumik CA, Roig-Junent S (2005) Criterio de optimación para áreas de endemismo: el caso de América del Sur Austral. In: LlorenteBousquets J, Morrone JJ (eds) Regionalización biogeográfica en Iberoamérica y tópicos afines. Las Prensas de Ciencias, UNAM, México, pp 495-508

Szumik CA, Cuezzo F, Goloboff P, Chalup AE (2002) An optimality criterion to determine areas of endemism. Syst Biol 51:806-816

Szumik C, Nomdedeu S, Panizza A, Aagesen L, Casagranda D, Navarro F, Diaz-Gomez JM, Sandoval M, Baldo D, San-Blas G, Cuezzo F, Taher L, Goloboff P, Lizarralde M, Zuloaga F (2007) Biogeografíca del norte Argentino (paralelos 21 a 32): primer ensayo utilizando vertebrados, insectos y plantas. Darwiniana 45:49-51

Szumik C, Aagesen L, Casagranda D, Arzamendia V, Baldo D, Claps LE, Cuezzo F, Diaz Gomez JM, Di Giacomo A, Giraudo A, Goloboff P, Gramajo C, Kopuchian C, Kretzschmar S, Lizarralde M, Molina A, Mollerach M, Navarro F, Nomdedeu S, Panizza A, Pereyra VV, Sandoval M, Sccrochi G, Zuloaga F (2012) Detecting areas of endemism with a taxonomically diverse data set: plants, mammals, reptiles, amphibians, birds, and insects from Argentina. Cladistics 28:317-329

Whittaker RJ, Araujo MB, Jepson P, Ladle RJ, Watson JEM, Willis KJ (2005) Conservation biogeography: assessment and prospect. Divers Distrib 11:3-23

Wilson JS, Gunnel CF, Wahl DB, Pitts JP (2012) Testing the species limits of the tarantulas (Araneae: Theraphosidae) endemic to Californiás Southern Coast Ranges, USA. Insect Conserv Diver 6(3):365-371 